\title{
DIRECTIONS OF DIGITAL TRANSFORMATION OF CREATIVE TECHNOLOGIES IN TOURISTIC FIELD AFTER THE COB OF THE COVID-19 PANDEMIC
}

\author{
(C) VENHERSKA, NATALIA \\ Zaporozhye National University (Zaporozhye, Ukraine) \\ E-mail: nataljavengerskaja@ukr.net \\ ORCID iD: http://orcid.org/0000-0001-8171-8206 \\ Запорізький національний університет, вул. Жуковського, 66, 69600 Запоріжжя, Україна \\ Zaporozhye National University, Zhukovskiy st., 66, 69600 Zaporozhye, Ukraine \\ (C) VORONKOVA, VALENTYNA \\ Engineering educational and scientific Institute \\ of Zaporozhye National University, Editor-in-Chief (Zaporozhye, Ukraine) \\ ORCID iD: http://orcid.org/ 0000-0001-5253-7481 \\ E-mail: valentinavoronkova236@gmail.com \\ Інженерний навчально-науковий інститут ім. Ю.М.Потебні, Запорізький національний університет, \\ пр. Соборний, 226, 69006 Запоріжжя, Украӥна \\ Engineering educational and scientific Institute named after Y.M. Potebnya of Zaporozhye National University, \\ 226 Soborny Avenue \\ (C) CHEREP, ALLA \\ Zaporozhye National University (Zaporozhye, Ukraine) \\ E-mail: cherep.av.znu@gmail.com \\ ORCID iD: http://orcid.org/ 0000-0002-0719-1546 \\ Запорізький національний університет, вул. Жуковського, 66, 69600 Запоріжжя, Україна \\ Zaporozhye National University, Zhukovskiy st., 66, 69600 Zaporozhye, Ukraine, 69006 Zaporozhye, Ukraine \\ (C) CHEREP, OLEKSANDR \\ Zaporozhye National University (Zaporozhye, Ukraine) \\ E-mail: cherep2508@gmail.com \\ ODCID iD: http://orcid.org: 0000-0002-3098-0105 \\ Запорізький національний університет, вул. Жуковського, 66, 69600 Запоріжжя, Украӥна \\ Zaporozhye National University, Zhukovskiy st., 66, 69600 Zaporozhye, Ukraine \\ (C) BEZKOROVAINA, LARYSA \\ Zaporozhye National University (Zaporozhye, Ukraine) \\ E-mail: lvbeskorovaynaya@gmail.com \\ ORCID iD: https://orcid.org/0000-0001-9502-9604 \\ Запорізький наиіональний університет, вул. Жуковського, 66, 69600 Запоріжжя, Украӥна \\ Zaporozhye National University, Zhukovskiy st., 66, 69600 Zaporozhye, Ukraine
}

\begin{abstract}
The relevance of the research topic lies in the fact that the digital transformation of creative technologies in touristic field is seen as an important sustainable development element of an economy and society in 2030 context. Creative technologies, the data revolution and the digitalisation of governments are key elements and vital to fostering collaboration between governments, the private sector and civil society, helping to improve the efficiency of the tourism sector and service delivery. The purpose of the article is to conceptualize digital transformation of creative technologies in the touristic field after the COVID-19 pandemic. Some aspects are being studied by experts on the digital transformation of creative technologies in tourism, which was hit after the COVID-19 pandemic, including creative innovative technological impact on sustainable tourism in Europe, analyzed in articles and reports, tourism forums and conferences. The authors used their own developments on this topic L. Bezkorovaina, N. Vengerska, V. Voronkova, A. Cherep, O. Cherep. The research is based on the use of a modified information-logical model, which establishes the relationship between the identified bottlenecks in tourism, the causes of their occurrence and possible ways to eliminate these causes, which developed
\end{abstract}

(C) Venherska, Natalia, Voronkova, Valentyna, Cherep, Alla, Cherep, Oleksandr, Bezkorovaina, Larysa, 2021 
practical recommendations for improving tourism including greens. The result of the research. The digital transformation of creative technologies in touristic field as an important element of sustainable development of the economy and society is analyzed. Digital transformation key areas of creative technologies in touristic field have been identified: climate changing issues and recovery of the world economy. The directions of transition to green creative technologies as a set of measures for post-pandemic recovery are revealed. European paradigm development of urban tourism in the context of differentiation and development of domestic tourism is clarified. Adaptation to digital transformation - an already existing trend accelerated by the COVID-19 pandemic - is one of the main priorities for the development of digital technologies.

Keywords: digital transformation, creative technologies, tourism, sustainable economic development, green creative technologies, post-pandemic renewal of tourism, urban tourism.

Problem statement in general and its connection with important scientific or practical tasks

Digital technologies and the data revolution offer the potential to increase the efficiency, transparency, responsiveness and trust of citizens, directly affecting the quality of tourism services, overcoming the crisis, helping to improve governance through the use of digital tools and GovTech. Creative technologies, the data revolution and the digitalisation of governments are key elements and vital to fostering collaboration between governments, the private sector and civil society, helping to improve the efficiency of the tourism sector and service delivery. Sustainable Digital transformation of creative technologies in touristic field is one of the five priorities of the European Commission's policy on the Eastern Partnership after 2020. Its implementation is supported by the European initiative EU4Digital, aimed at expanding the EU digital market to Eastern partner countries, developing the potential of the digital economy and digital tourism.

Analysis of recent research and publications, which initiated the solution of this problem and on which the authors rely

Some aspects are being studied by experts on the digital transformation of creative technologies in tourism, which was hit after the COVID-19 pandemic, including the impact of creative innovative technologies on sustainable tourism in Europe, analyzed in articles and reports, tourism forums and conferences. The authors used their own developments on this topic L. Bezkorovaina, N. Vengerska, V. Voronkova, A. Cherep, O. Cherep.

Highlighting previously unsolved parts of the general problem to which this article is devoted

The heart of the research is an unresolved issue the sustainable digital transformation of creative technologies in touristic field as one of the five priorities of the European Commission's policy on the Eastern Partnership after 2020. Its implementation is supported by the European initiative EU4Digital, aimed at expanding the EU digital market to Eastern partner countries, to develop the potential of the digital economy. Basic science should present the meaning of the phenomenon and propose its heuristic model, because science means objectively reliable and systematic knowledge of the natural phenomena and human life, presented in terms of their regularity and further development.

Purpose and formation of the goals in the article (task setting):

The purpose of the article is to conceptualize the digital transformation of creative technologies in touristic field after the COVID-19 pandemic.

\section{Objectives of the research:}

- to analyze the digital transformation of creative technologies in touristic field as an important element of sustainable development of the economy and society;

- identify digital transformation key areas of creative technologies in touristic field: climate change and global economic recovery;

- to reveal the directions of transition to green creative technologies as a set of measures for postpandemic recovery;

- to find out the development of the European paradigm of urban tourism in the context of diversification and development of domestic tourism.

Presentation of the main material of the research with substantiation of the obtained scientific results

1. Digital transformation of creative technologies in touristic field as an important element of sustainable development of the economy and society.

The digital transformation of creative technologies in touristic field is seen as an important element of sustainable development of the economy and society in 2030 context. These include the Internet of Things (IoT), cloud technology, electronic identification (eID) and artificial intelligence (AI) can help achieve global sustainable development goals. The digital transformation of creative technologies in touristic field is an integral part of the transition to a sustainable economy, which requires investment in improving digital communication with the EU's external partners. Basic science must respond to 
such radical changes, study the development of these phenomena and processes and draw conclusions for their implementation [1].

The digital transformation of creative technologies in touristic field covers four main areas:

1) citizens who have digital skills;

2) highly qualified specialists in the field of information technology;

3) secure, productive and sustainable digital infrastructures;

4) business and digitalization IT transformation of public services. Scientific idea mastery of creative technological transformation should end with the construction of a heuristic model of touristic development in the post-pandemic era, as it «raises» our understanding to a higher level, which is discussed in the research objectives.

In this regard, every effort is being made to facilitate the rapid launch of global projects, to promote the digital agenda in international organizations and in global digital partnerships. Combining the European Union's internal investment with large external funding will allow the EU to work with partners around the world to achieve common global goals; You can invest in improving communication with the EU's external partners by setting up a Digital Communication Fund. The digital skills situation in the EU's neighboring countries is improving, according to the European Training Foundation [2].

According to the foundation's research, most of the EU's neighbors have already equipped schools with computers and internet access; in most Eastern Partnership countries, network access is almost $100 \%$. Despite all the positive steps, much remains to be done to ensure an equal digital society for women and men.

Sustainable Digital transformation of creative technologies in touristic field is one of the five priorities of the European Commission's policy on the Eastern Partnership after 2020. Its implementation is supported by the European initiative EU4Digital, aimed at expanding the EU digital market to Eastern partner countries, to develop the potential of the digital economy.

Countries such as Finland, Germany and Hungary are better prepared than others to implement $5 \mathrm{G}$; $22 \%$ of households do not yet have a fixed broadband subscription in 2019; 4G networks cover almost the entire population of Europe; only $18 \%$ of ICT professionals are women; 17 Member States are connected to $5 \mathrm{G}$ bands; $32.5 \%$ of large companies use big data analytics; the use of video calls increased to $60 \%$ in $2019 ; 42 \%$ of the EU population does not yet have basic digital skills. Digital technologies are important in life - from remote work, online medical consultations to video calls. The pandemic shows that Europe is lagging behind in the use of digital technologies: almost a quarter of homes do not have broadband internet, and less than $20 \%$ of small businesses use the internet to sell their products or services. The transition to a digital system is a key element of the EU's recovery from the pandemic. It is based on the restoration of sustainability, for which 672.5 billion euros have been allocated, which will be spent on public investment and reforms [3].

The digital transformation of creative technologies in touristic field today is changing the way we live and work: there is a gap between the «rich» and the «poor»; $42 \%$ of Europeans do not have basic digital skills, $83 \%$ of small and medium-sized enterprises do not use cloud Internet services. Digital technologies are needed to ensure the overall success of the project in many areas: the EU promotes investment in high-speed broadband, training people in digital skills, helping start-ups and small businesses to innovate and develop, and using technology to ensure climate neutrality [4].

Already today, the Scandinavian countries and the Netherlands occupy leading positions in the field of digitalization; According to the United Nations, Denmark is a world leader in e-government, with all sectors of the economy switching to digital. Denmark has requested 1.6 billion euros in subsidies and is to allocate one-fifth of this amount to digital switches. 134.5 billion euros will be allocated from the EU's reconstruction fund for digitization.

Digital technologies apply to all sectors of the economy, they can be used to improve governance, health care systems, and the competitiveness of companies to affect the entire economy. The top technologies include applied artificial intelligence, active development of computer vision, natural language programming and spoken technologies. Other trends include a new level in automation and virtualization processes, next-generation wireless communications, distributed infrastructure, nextgeneration computing, and software 2.0. This is by no means a complete list of trends and trends in digitalization in the EU.

Adaptation to digital transformation - an already existing trend accelerated by the COVID-19 pandemic - is one of the main priorities for the development of digital technologies.

Digital transformation of creative technologies in touristic field is reduced to:

(C) Venherska, Natalia, Voronkova, Valentyna, Cherep, Alla, Cherep, Oleksandr, Bezkorovaina, Larysa, 2021 
1) implementation of the European Green Course, introduction of new technologies and reduction of harmful CO2 emissions, improvement of air and water quality, establishment of new rules for the use of mineral fertilizers, promotion to the so-called «circular» renewable economy;

2) digital transformation, which provides for the introduction of new regulatory rules to increase the stability of the digital market, solve the problem of dependence on external supply of semiconductors, create a favorable ecosystem for the development of innovative digital technologies in the EU. The digital transformation of creative technologies in touristic field also includes a combination of Member States' efforts for sustainability in the field of cyber security, development of secure satellite communication systems, raising the general educational level of the European population in mastering digital technologies;

3) targeted efforts to restore economic activity in the EU after the COVID-19 crisis, increase social protection and social standards for the European population;

4) strengthening the EU's position in the world, which involves the active development of trade and investment, and strengthening relations with key partners. By the end of 2021, the EU intends to sign a new Joint Declaration with NATO, which should be a practical step towards strengthening the European Defense Alliance;

5) promoting the European way of life and protecting European democracy, including the implementation of broad social programs, the qualitative improvement of the education system, the strengthening of the health care system and the prevention of future crises in this area. Today, the latest digital technologies need to be developed, especially in terms of accessibility and innovation, including overcoming inequalities in access to digital resources, improving the digitization of cultural content to ensure fairer access [5].

2. Digital transformation key areas of creative technologies in touristic field: climate change and global economic recovery

Among the digital transformation key areas of creative technologies in touristic field - the issue of climate change and world economic recovery. The G20 sought to emphasize that rich countries should spend $\$ 100$ billion a year to help poorer nations adapt to climate change. Ukraine has supported a plan to create a global power grid aimed at accelerating the global transition to alternative energy. At the COP26 climate summit in Glasgow, the United Kingdom and India presented a plan to create a global energy network that will accelerate the global transition to alternative energy. The UN proposes to write off debts to poor countries due to the pandemic. UN Secretary-General Antonio Guterres has called on the world community to write off debts to poor countries due to the coronavirus pandemic, or at least postpone their repayment until the end of 2021 [6].

Due to the COVID-19 crisis, the flows of foreign direct investment and financial transactions sharply decreased, and the volume of external debt increased sharply. In this regard, rich countries must go to write off debts to some countries, or at least delay their repayment.

After all, the pandemic has demonstrated the fragility not only of health systems but also global institutions of governance and multilateralism, so governments must tackle the crisis and build a «better future» as they recover. In addition to the pandemic and its aftermath, the G20 summit discussed accelerating global economic recovery, addressing rising energy prices and supply chain disruptions affecting a number of key industries around the world; global warming and change and addressing global challenges affecting the economy; fight against cross-border corruption and tax problems; economic revival after the pandemic; rapid and sustainable recovery of tourism and resumption of international travel [7].

Digital technologies have expanded their impact on the agri-food sector, which can use digital tools, from e-commerce and mobile technologies to expand market access to artificial intelligence to improve pest control and crop genetics, as well as tools to enable optimize natural resource management and early warning systems. This will contribute to a holistic approach that combines economic, social and environmental aspects to achieve the goals of sustainable development. The pandemic has accelerated and expanded the use of digital technologies, but it has revealed a deeper digital divide in rural areas. Lack of digital skills, poor communication and lack of investment in the development of small farms are the obstacles we need to overcome. On the positive side, the pandemic has helped to restore the city's connections with nature and opens up opportunities for agritourism, which is valued today. Establishing links between smart cities and smart villages is an option that needs to be considered in the near future to reduce the digital divide in rural areas [8].

One of the directions of digital transformation of creative technologies in touristic field after the impact 
of the COVID-19 pandemic is the huge number of barriers of both technological and regulatory nature. Digitalization in the field of transport has many advantages, but care must be taken, because all these changes lead to changes in standardization, necessary changes in legislation. It is extremely important for the government and state structures to make decisions in the legal field that will differentiate the rights of possession of data, access to data. There are some very interesting solutions in European countries, but they need to be a lever for the digital economy and transport. It is necessary to determine the concept of data ownership as soon as possible, to understand who owns the data. Accordingly, it is impossible to build business models of their monetization. Insufficient pace of transition to electronic document management. The benefits of using e-transport invoices are obvious. If the business is moving to electronic document management, and some of these documents remain on paper, the benefits of moving to digital are not so obvious, so it is necessary to translate the huge paperwork made on paper into digital circulation. In order to make the «digital» path of passengers easier, it is necessary to remove the regulations on digital boarding passes. There is a lack of a single database of transport and logistics data, how to connect the roads schedule, possible routes from point $A$ to point $B$, how to start digitization of these processes. There is a lack of data, not the whole country is digitized in one coordinate system, there is a need to obtain a single information base [9].

3. Promoting the transition to green creative technologies as a set of measures for postpandemic recovery

Incorporating green economy goals into a package of post-pandemic recovery measures will increase resilience to future shocks as well as reduce risks. Measures to encourage the introduction of green creative technologies, including efforts to improve energy efficiency through the conversion of buildings can have large fiscal multipliers, as they are time consuming and increase productivity [10].

In the short term, measures to create environmentally friendly physical infrastructure, modernize energy efficiency, invest in education and training, invest in natural capital, clean research and development, and in low- and middle-income countries will be effective. support for rural areas.

Improving energy efficiency, conserving nature, using clean energy sources, sustainable development of the transport sector, which are among the priority areas for investment, stimulate «green» creative development (Hallegatte and Hammer 2020). Bridging the gap between the current spending level and the level required to achieve the Sustainable Development Goals can contribute to sustainable per capita income growth [11].

Prioritizing investments in high-impact green infrastructure projects and encouraging the widespread adoption of environmentally sustainable creative technologies can support higher growth rates in the long run while mitigating climate change. Improving resilience to climate change risks, such as increasing the frequency of severe hurricanes and droughts, rising sea levels and declining crop yields, is vital for the ECA region, especially given that the region has many agricultural exporters. products, and a significant part of the population lives on the coast.

Over $80 \%$ of agricultural land is expected to be depleted in the coming decades due to reduced rainfall (European Environmental Agency 2019). The cost of investing in sustainable infrastructure can be offset by targeted measures to ensure rapid job creation, including the introduction of drought control technology, landscape and watershed management, ecosystem restoration and sustainable forest management. For many emerging markets and emerging economies, investing in renewable energy can help increase energy security while reducing dependence on electricity imports [12].

These investments can also reduce the burden on budgets related to the provision of energy subsidies, which are quite large in the ECA countries and in 2019 averaged over 3\% of GDP (IEA 2020). The fiscal stimulus provided to date in the G20 as part of pandemic measures has been designed to support both carbon and environmentally sound activities. Green technologies (also environmental technologies, green technology, greentech) technologies whose production processes and supply chains are environmentally friendly or less harmful compared to traditional methods of production. These technologies are implemented in the environmental, economic, technological and innovative spheres and address waste management, the use of alternative energy sources, etc. [1].

Examples of the use of such technologies are biological water treatment, hydropower, solar energy, green ICT, disposal of all rubish types (WMD), including technologies for recovery of organic waste. In the 1970 s, a number of countries began trying to introduce the use of solar energy and other alternative power sources to reduce dependence on fossil fuels. However, green technology in the modern

(C) Venherska, Natalia, Voronkova, Valentyna, Cherep, Alla, Cherep, Oleksandr, Bezkorovaina, Larysa, 2021 
sense appeared in 2001 in the United States, when in California there were fan power outages, which required the use of alternative power sources. After this event, companies engaged in green technologies are gaining new development.

In particular, in 2005, SunPower, a solar company, launched an IPO and increased its capital. At the same time, Bloom Energy is beginning to develop solid oxide fuel cells that generate electricity, which allows you to abandon the centralized power supply system. GreenFuel Technologies, originally a startup at Harvard University, has proposed technology to create biofuels from seaweed. Later, Tesla will be created to manufacture electric vehicles [13].

Green creative technologies can promote sustainable development by preventing resource depletion; produce goods that can be recycled, recovered or reused; reduce environmental pollution by increasing resource efficiency of production; apply innovations that replace old methods of energy production that harm the environment; to promote economic development, creation of new technologies and goods [14].

In the European Union, green creative technologies are understood as «the best available technologies», which should minimize environmental pollution by introducing such technologies. However, one of the main problems in the introduction of green technologies is their high cost, high time costs, as well as negative environmental consequences; unwillingness of the population, business and government to implement green technologies; shortage of qualified specialists who can manage the introduction of green technologies; high costs of changing transport and energy infrastructure; uncertainty of the results that green technologies can provide. China is one of the largest investors in solar and wind energy. To attract investors, special Green Funds are created, the task of which is to form investments, including in the development of green technologies. Green creative technologies in Europe and Central Asia are closely linked to green policy and the development of creative green technologies.

4. Development of the European urban tourism paradigm: differentiation and development of domestic tourism

Despite the fact that it is still difficult to understand what will happen in the post-pandemic era with the development of tourism in major urban centers in Europe, it is safe to say that their future will be determined by political choices made in the coming years. The main problem in rethinking urban centers is that cities today have become empty shells. In a time of severe economic crisis, there is a risk that Italy will continue to rely on short-sighted policies that put the imperfect tourism model at the forefront of its economy. However, the existential crises that have affected the urban centers of Italy and Europe open up opportunities for a new, more sustainable paradigm of urban tourism. The question arises: is it possible to combine social justice and sustainability with mass tourism? The mayors of some of Europe's most visited cities say it's possible. According to Xavier Marce, a member of Barcelona's tourism council, the problem is not the number of tourists, but their distribution: a more even distribution of places and seasons would make management easier. Although redirecting to where people want to go is not easy, decentralizing tourist destinations would allow more peripheral places to benefit from the prosperity that tourism can bring [15]. However, according to the OECD report on tourism trends in 2020, without the right policy, the redistribution of visitors could simply move problems elsewhere. Even before the pandemic, major European tourist destinations, such as Amsterdam, Barcelona and Paris, had developed containment strategies to make tourism more sustainable. To combat gentrification, pollution and overcrowding, these cities have developed policies to regulate housing and deter violations in the tourism and hospitality sectors. The most pressing issue for many cities remains how to populate historic centers and create a new foundation for residents and tourists to live side by side. For Minoa, cities should hinder the dominance of tourism, even limiting, if necessary, the number of tourists. This period gave rest to people and the environment; the model of urban tourism we used before involved the conquest of lands and cities, which in itself we cannot even call tourism. Now we need to defend city life [16]. Following the pandemic, it is hoped that rented apartments and empty buildings in Venice will be redistributed among university students, social enterprises and affordable housing for residents. But without adequate government incentives and regulation, not to mention a plan to restore the ecosystems of historic centers and neighborhoods, the hearts of cities will remain in the grip of mass tourism or, worse, remain uninhabited. The conditions created by the pandemic allow to revive these traditions, at the same time promoting new types of employment. There is a real desire among young people to breathe new life into new crafts, which will contribute to the development of creative technologies by strengthening the Creative 
Europe program. Restoring the social fabric will also help prevent a monoculture of tourism and will contribute to greater diversification, so that a similar social crisis provoked by Covid-19 does not happen again. While cities are empty, political debates in Italy are about getting tourists back as soon as possible, focusing on promoting domestic tourism, and making urban centers safe and attractive again [17].

\section{Conclusions and practical recommendations}

1. It is necessary to update and stabilize economic models of digital transformation of creative technologies in touristic field due to the devastating impact of the pandemic and the need to form new economic models, especially for cultural and rural tourism; strengthening the synergy between culture and education so that students can develop new skills, become active citizens and adapt to the fastgrowing labor market, and therefore put culture and rural tourism at the heart of the European paradigm. It is important for all countries to prepare for the next pandemics and increase funding for health care. This topic is one of the main directions of the economic recovery of the world after the pandemic, along with energy and the recovery of the financial sector. Leaders of the 20 largest economies in the world gathered in Rome on October 30, 2021 for the first two-day G20 summit since the beginning of the pandemic

2. It is necessary to create integrated digital platforms, to develop a digital platform of the transport complex, which will allow to act as a trust environment, which on the one hand will receive information from different platforms in the form of data and transmit it to state regulatory authorities. Within the digital platform of the transport complex to create a system of tracking freight transport, a technological solution in the form of a navigation solution, which today is an on-board computer that can hold various information. Prepare a bridgehead for the creation and provision of multimodal services for our customers, actively develop a platform for freight.

3. Taking into account the analysis based on empirical data, strategic recommendations for the use of the revolution in the field of data to improve the tourism sector. These recommendations are as follows: (a) implementation of mechanisms that encourage the implementation and adaptation of data collection, processing and storage systems in the development of tourism services; (b) expanding the impact of the data revolution by increasing the digitalisation of travel agencies and ensuring the coordination of decentralized data collection, processing and storage systems; (c) encouraging the development of platforms that ensure the accountability of travel agencies on issues such as the general approach to data use; (d) direct feedback between business leaders and organizations and tourists in order to expand links and improve the work of the tourism industry.

An important field of future research should be its transition from philosophy to basic science, which should enrich us with a complete model of digital transformation of creative technologies in tourism after the COVID-19 pandemic, and become a standard for its use in various applied sciences.

The publication was prepared within the project "Diversification of rural tourism through sustainability and creativity: disseminating European experience in Ukraine» / "Diversification of rural tourism through sustainability and creativity: disseminating European experience in Ukraine». (DIRUT) 620720-EPP1-2020-1-UA-EPPJMOMODULE with the support of the Erasmus +: Jean Monnet Program of the European Union, implemented at Zaporizhia National University (2020-2023).

\section{Список використаних джерел}

1. Андрюкайтене Регіна, Воронкова В.Г. Цифрова трансформація електронної освіти в країнах Європейського Союзу. Розвиток сучасної науки та освіти: реалї̈, проблеми якості, інновації : матер. II Міжнародної наук.-практ. інтернет-конф. (Мелітополь, 25-27 травня 2021 р.) / ред. кол. : В.М. Кюрчев, Н.Л. Сосницька, М.I. Шут та ін. Мелітополь : ТДАТУ, 2021. С. 88-91

2. Венгерська Н. С., Воронкова В. Г., Бескоровайна Л. В. \& Череп А. В. Використання креативних цифрових технологій у сфері туризму під час пандемії COVID-19: економічні і соціальні наслідки. Hитапіties studies : Collection of Scientific Papers. Zaporizhzhia : Zaporozhye National University, 2021. Вип. 7(84). С. 91-101. doi: https://doi.org/10.26661/hst-2020-7-8-12

3. Венгерська Н.С., Череп А.В., Воронкова В.Г., Безкоровайна Л.В. Цифрова трансформація електронної освіти в країнах ЄС: поширення європейського досвіду в Україні. Свропейський вектор модернізації інженерної та економіко-управлінської освіти в умовах сталого розвитку промислового регіону : матеріали Міжнародної науково- практичної конференції (27-28 травня 2021 року, м. Запоріжжя) / наук. ред. Н.Г. Метеленко. Запоріжжя : ЗНУ Інженерний навчально-науковий інститут, 2021. С. 220-223.

(C) Venherska, Natalia, Voronkova, Valentyna, Cherep, Alla, Cherep, Oleksandr, Bezkorovaina, Larysa, 2021 
4. Безкоровайна Л.В., Воронкова В.Г., Венгерська Н.С. Сільський креативний туризм: досвід інтегрованого підходу в Португалії. Управління сочіально-економічним розвитком регіонів та держави : матеріали Міжнародної конференції 15 квітня 2021 року. Запоріжжя : ЗНУ, 2021.

5. Безкоровайна Л. В. Теоретичні і методичні засади професійної підготовки майбутніх фахівців з туризмознавства у вищих навчальних закладах : дис. ... д-ра пед. наук: 13.00.04 / Запорізький національний університет. Запоріжжя, 2018. $713 \mathrm{c.}$

6. Воронкова В.Г., Нікітенко В.О. Цифрова трансформація Свропи «Цифровий компас-2030» як умова подолання пандемії COVID-19: цифровізація економіки, освіти і медицини. Розвиток сучасної науки та освіти: реалії, проблеми якості, інновації : матер. II Міжнародної наук.-практ. інтернет-конф. (Мелітополь, 25-27 травня 2021 р.) / ред. кол. : В.М. Кюрчев, Н.Л. Сосницька, М.І. Шут та ін. Мелітополь : ТДАТУ, 2021. С. 92-96.

7. Воронкова В.Г., Череп А.В. Креативні цифрові технології як мегатренди розвитку туристичного бізнесу: поширення європейського досвіду в Україні. Humanities studies : збірник наукових праць / гол. ред. В.Г. Воронкова. Запоріжжя : Запорізький національний університет, 2020. Вип. 6(83). С. 165-179. http://humstudies.com.ua/article/ view/227431

8. Воронкова Валентина, Кивлюк Ольга. Smart-інновації як нова парадигма розвитку smart-суспільства: зарубіжний досвід. Концептуальні та практичні засади становлення і розвитку smart-освіти як чинника формування sтаrt-культури в умовах еволюиії від інформаційного суспільства до «smart-cyсnільства» : матеріали Міжнародної науково-практичної конференції 19-20 грудня 2018 року / ред.-упорядник: д.філософ.н., проф. В.Г. Воронкова. Запоріжжя : Вид-во ЗДІА, 2018. С. 88-91. http://www.zgia.zp.ua/index.php?page=4415\&lang=ua

9. Voronkova, V., Nikitenko, V., Oleksenko, R., Cherep, O., Andriukaitiene, R., Briki, I. Digital paradigm of economy and management in the conditions of global human transformation. Technology Transfer: Innovative Solutions in Social Sciences and Humanities. 2021. Is. 4. Pp. 37-40. doi: http://doi.org/10.21303/2613-5647.2021.001769

10. Воронкова В.Г., Пунченко Н.О. Формирование трендов информационно-компьютерных технологий как проявления глобальных тенденций развития цифрового мира. Mokslas ir praktika: aktualijos ir perspektyvos Taptautiné mokslinè : praktinè konferencija 2019 m. gegužės 09-10 may, Kaunas.

11. Воронкова В.Г. Інноваційні аспекти розвитку креативних технологій національної й світової індустрії туризму в умовах COVID-19. Інновачійні рішення в економіці, бізнесі, суспільних комунікаціях та міжнародних відносинах : матеріали Міжнародної науково-практичної інтернет-конференції. Дніпро : Університет митної справи та фінансів, 2021. С. 458-462.

12. Нікітенко В.О. Концепція активізації розвитку туристичного менеджменту в умовах COVID-19. Інноваційний розвиток сучасної економіки: нові підходи та актуальні дослідження : матеріали Всеукраїнської науково-практичної конференції / Запорізький національний університет. Запоріжжя : ЗНУ, 2021. С. 67-70.

13. Punchenko, Oleg, Voronkova, Valentyna \& Vodop'yanov, Pavel. Health care as a global problem of humanity and its relationship with other global problems. Humanities studies : Collection of Scientific Papers. Zaporizhzhia : Zaporozhye National University, 2021. No. 7(84), Pp. 39-47. doi: https://doi.org/10.26661/hst-2020-7-84-05

14. Фурсін О.О. Комунікаційний менеджмент як система соціальної взаємодії та «буття людини в комунікації». Інноваційний розвиток сучасної економіки: нові підходи та актуальні дослідження : матеріали Всеукраїнської науково-практичної конференції / Запорізький національний університет. Запоріжжя : ЗНУ, 2021. С. $70-73$.

15. Череп А.В., Воронкова В.Г. Концепція креативних технологій у туристичному бізнесі. Виклики європейської регіональної політики в умовах пандемії COVID-19 : збірник матеріалів міжнародного круглого столу. Тернопіль : ЗУНУ, 2020. С. 54-58.

16. Череп А.В., Воронкова В.Г., Андрюкайтене Регіна, Нікітенко В.О. Концепція креативних цифрових технологій у туристичному бізнесі. Humanities studies : збірник наукових праць / гол. ред. В.Г. Воронкова. Запоріжжя : Запорізький національний університет, 2020. Вип. 5(82). С. 196-209. http://humstudies.com.ua/article/view/220949

17. Череп А.В., Воронкова В.Г., Череп О.Г., Венгерська Н.С., Безкоровайна Л.В. Вплив креативних інноваційних технологій на сталий розвиток туристичної галузі в Європі після пандемії COVID-19. Humanities studies : Collection of Scientific Papers. Zaporizhzhia : Zaporozhye National University, 2021. Is. 8(85). Pp. 134-146.

\section{References}

1. Andryukaitene, R., \& Voronkova, V. (2021). Digital transformation of e-education in the countries of the European Union. Development of modern science and education: realities, quality problems, innovations : mater. II International scientific-practical. internet conference (Melitopol, May 25-27, 2021) / ed. count. : V. Kyurchev, N. Sosnitskaya, M. Shut and others. Melitopol : TSATU, Pp. 88-91.

2. Venherska, N., Voronkova,V., Beskorovaina, L. \& Cherep, A. (2021). The use of creative digital technologies in tourism during the pandemic COVID-19: economic and social consequences. Humanities studies : Collection of Scientific Papers. Zaporozhye : Zaporozhye National University, Is. 7(84). Pp. 91-101. doi: https://doi.org/10.26661/hst-2020-7-8-12

Directions of digital transformation of creative technologies in touristic field after the cob of the COVID-19 pandemic 
3. Venherska, N., Cherep, A., Voronkova, V., \& Bezkorovaina, L. (2021). Digital transformation of e-learning in EU countries: dissemination of European experience in Ukraine. European Vector of Modernization of Engineering and Economic Management in Sustainable Development of Industrial Region : Proceedings of the International Scientific and Practical Conference (May 27-28, 2021, Zaporozhye) / Science. ed. N. Metenko. Zaporozhye : ZNU Engineering Educational and Scientific Institute. Pp. 220-223.

4. Bezkorovaina, L., Voronkova, V., \& Venherska, N. (2021). Rural creative tourism: the experience of an integrated approach in Portugal. Management of socio-economic development of regions and the state : International Conference, April 15, 2021. Zaporozhye : ZNU.

5. Bezkorovaina L. (2018). Theoretical and methodical principles of professional training of future specialists in tourism in higher education : dis. Dr. Ped. Sciences: 13.00.04 / Zaporozhye National University. Zaporozhye. $713 \mathrm{p}$.

6. Voronkova, V., \& Nikitenko, V. (2021). Digital Transformation of Europe "Digital Compass-2030" as a condition for overcoming the pandemic COVID-19: digitalization of economics, education and medicine. Development of modern science and education: realities, quality issues, innovation : mater. II International scientific-practical internet conference (Melitopol, May 25-27, 2021) / ed. count.: V. Kyurchev, N. Sosnitskaya, M. Shut and others. Melitopol : TSATU. Pp. 92-96.

7. Voronkova,V., \& Cherep, A. (2020). Creative digital technologies as megatrends of tourism business development: dissemination of European experience in Ukraine. Humanities studies : collection of scientific works / ed. V. Voronkova. Zaporozhye : Zaporozhzhia National University. Is. 6(83). Pp. 165-179. http://humstudies.com.ua/article/view/ 227431

8. Voronkova, Valentina, \& Kivlyuk, Olga (2018). Smart-innovations as a new paradigm of smart-society development: foreign experience. Conceptual and practical principles of formation and smart education development as a factor in the formation of smart culture in the evolution from information society to "smart society" : Proceedings of the International Scientific and Practical Conference on December 19-20, 2018 / editor-in-chief: Doctor of Philosophy, Prof. V.G. Voronkova. Zaporozhye : ZDIA Publishing House. Pp. 88-91. http://www.zgia.zp.ua/index.php?page= 4415\&lang=ua

9. Voronkova, V., Nikitenko, V., Oleksenko, R., Cherep, O., Andriukaitiene, R., \& Briki, I. (2021). Digital economic and management paradigm in global human transformation conditions. Technology Transfer: Innovative Solution in Social Science and Humanity. Is. 4, Pp. 37-40. doi: http://doi.org/10.21303/2613-5647.2021.001769

10. Voronkova, V., \& Punchenko, N. (2019). Formation of information and computer technology trends as a manifestation of global trends in the digital world. 0.2 Practice and practice: current and perspectives. Taptautine moksline : praktinè konferencija 2019 m. available 09-10 May, Kaunas.

11. Voronkova, V. (2021). Innovative development aspects of national and world tourism industry creative technologies in conditions of COVID-19. Innovative solutions in economics, business, public communications and international relations : materials from International scientific-practical Internet conference. Dnipro : Customs and Finance University. Pp. 458-462.

12. Nikitenko, V. (2021).The intensifying development concept of tourism management in terms of COVID-19. Innovative development of modern economy: new approaches and current research : Proceedings of the All-Ukrainian scientific-practical conference / Zaporozhye National University. Zaporozhye : ZNU. Pp. 67-70.

13. Punchenko, Oleg, Voronkova, Valentyna, \& Vodopyanov, Pavel (2021). Health care as a global humanity and relationship problem with other global problems. Humanities studies : Collection of Scientific Papers. Zaporozhye : Zaporozhye. National University, Is. 7(84). Pp. 39-47. doi: https://doi.org/10.26661/hst-2020-7-84-05

14. Fursin, O. (2021). Communication management as a system of social interaction and "human existence in communication". Innovative development in modern economy: new approaches and current research: Proceedings of the All-Ukrainian scientific-practical conference / Zaporozhye National University. Zaporozhye : ZNU. Pp. 70-73.

15. Cherep, A., \&Voronkova, V. (2020). The creative technological concept in the tourism business. Challenges of European regional policy in the context of the COVID-19 pandemic : a collection of international round table materials. Ternopil : ZUNU. Pp. 54-58.

16. Cherep, A., Voronkova, V., Andryukaitene, R., \& Nikitenko, V. (2020). The concept of creative digital technologies in the tourism business. Humanities studies : collection of scientific works / ed. V.G. Voronkov. Zaporozhye : Zaporozhye National University. Is. 5(82). Pp. 196-209. http://humstudies.com.ua/article/view/220949

17. Cherep, A., Voronkova, V., Cherep, O., Venherska, N., \& Bezkorovaina, L. (2021). The impact of creative innovative technologies on the sustainable development of tourism industry in Europe after the COVID-19 pandemic. Humanities studies : Collection of Scientific Papers. Zaporozhye : Zaporozhye National University. Is. 8(85). Pp. 134-146.

(C) Venherska, Natalia, Voronkova, Valentyna, Cherep, Alla, Cherep, Oleksandr, Bezkorovaina, Larysa, 2021 
ВЕНГЕРСЬКА, Н. С. - кандидат економічних наук, доцент кафедри міжнародної економіки, природних ресурсів та економіки міжнародного туризму

Запорізький національний університет (Запоріжжя, Україна)

E-mail: nataljavengerskaja@ukr.net

ORCID iD: http://orcid.org/0000-0001-8171-8206

ВОРОНКОВА, В. Г. - доктор філософських наук, професор, Академік академії наук вищої освіти України, завідувач кафедри менеджменту організацій та управління проектами

Інженерний навчально-науковий інститут ім. Ю. М. Потебні Запорізького національного університету (Запоріжжя, Україна)

E-mail: valentinavoronkova236@gmail.com

ORCID iD: http://orcid.org/ 0000-0002-0719-1546

ЧЕРЕП, А. В. - доктор економічних наук, професор, декан факультету економіки, Заслужений діяч науки і техніки України, Академік академії наук вищої освіти України

Запорізький національний університет (Запоріжжя, Україна)

E-mail: cherep.av.znu@gmail.com

ORCID iD: http://orcid.org/ 0000-0001-5253-7481

ЧЕРЕП, О. Г. - доктор економічних наук, професор, професор кафедри управління персоналом і маркетингу,

Запорізький національний університет (Запоріжжя, Україна)

E-mail: cherep2508@gmail.com

ODCID iD: http://orcid.org: 0000-0002-3098-0105

БЕЗКОРОВАЙНА, Л. В. - доктор педагогічних наук, доцент, професор кафедри туризму та готельно-ресторанної справи

Запорізький національний університет (Запоріжжя, Україна)

E-mail: lvbeskorovaynaya@gmail.com

ORCID iD: https://orcid.org/0000-0001-9502-9604

\title{
НАПРЯМИ ЦИФРОВОЇ ТРАНСФОРМАЦІЇ КРЕАТИВНИХ ТЕХНОЛОГІЙ У СФЕРІ ТУРИЗМУ ПІСЛЯ УДАРУ ПАНДЕМІЇ COVID-19
}

\begin{abstract}
Анотація
Актуальність теми дослідження в тому, що цифрова трансформація креативних технологій у сфері туризму розглядається як важливий елемент сталого розвитку економіки та суспільства у контексті до 2030 року. Креативні технології, революція даних і цифровізація урядів $\epsilon$ ключовими елементами та життєво важливими чинниками сприяння співпраці між урядами, приватним сектором та громадянським суспільством, що сприяють підвищенню ефективності туристичного сектору та наданню послуг. Мета статті концептуалізація цифрової трансформації креативних технологій у сфері туризму після удару пандемії COVID-19. Деякі аспекти вивчаються фахівцями з цифрової трансформації креативних технологій у сфері туризму, що зазнала удару після пандемії COVID-19, зокрема вплив креативних інноваційних технологій на сталий розвиток туристичної галузі в Європі, що аналізувалися в статтях та аналітичних доповідях, на форумах та конференціях з туризму. Авторами використано власні напрацювання з даної теми Л. Безкоровайною, Н. Венгерською, В. Воронковою, А. Череп, О. Череп. Дослідження грунтується на використанні модифікованої інформаційно-логічної моделі, за допомогою якої встановлюються взаємозв'язки між виявленими вузькими місцями у сфері туризму, причинами їх виникнення та можливими способами усунення цих причин, для чого розроблено практичні рекомендації удосконалення туристичної галузі та впливу на них креативних технологій, включаючи зелені. Результат дослідження. Проаналізовано цифрову трансформацію креативних технологій у сфері туризму як важливий елемент сталого розвитку економіки та суспільства. Виявлено ключові сфери цифрової трансформації креативних технологій у сфері туризму: питання зміни клімату та відновлення світової економіки. Розкрито напрями переходу до зелених креативних технологій як комплексу заходів з постпандемічного відновлення. 3'ясовано розвиток європейської парадигми міського туризму у контексті диферсифікації та розвитку внутрішнього туризму. Адаптація до цифрової трансформації - вже
\end{abstract}

Directions of digital transformation of creative technologies in touristic field after the cob of the COVID-19 pandemic 
існуючої тенденції, яка прискорена пандемією COVID-19 є одним із основних пріоритетів розвитку цифрових технологій.

Ключові слова: цифрова трансформація, креативні технології, туризм, сталий розвиток економіки, зелені креативні технології, постпандемічне відновлення туризму, міський туризм

ВЕНГЕРСКАЯ, Н. С. - кандидат экономических наук, доцент кафедры международной экономики, природных ресурсов и экономики международного туризма

Запорожский национальный университет (Запорожье, Украина)

E-mail: nataljavengerskaja@ukr.net

ORCID iD: http://orcid.org/0000-0001-8171-8206

ВОРОНКОВА, В. Г. - доктор философских наук, профессор, Академик академии наук высшего образования Украины, заведующая кафедрой менеджмента организаций и управления проектами

Инженерный учебно-научный институт им. Ю.М.Потебни Запорожского национального университета (Запорожье, Украина)

E-mail: valentinavoronkova236@gmail.com

ORCID: http://orcid.org/ 0000-0001-5253-7481

ЧЕРЕП, А. В. - доктор экономических наук, профессор, Заслуженный деятель науки и техники Украины, Академик Академии наук высшего образования Украины, декан факультета экономики

Запорожский национальный университет (Запорожье, Украина)

E-mail: cherep.av.znu@gmail.com

ORCID iD: http://orcid.org/ 0000-0002-0719-1546

ЧЕРЕП, А. Г. - доктор экономических наук, профессор, профессор кафедры управления персоналом и маркетинга

Запорожский национальный университет (Запорожье, Украина)

E-mail: cherep2508@gmail.com

ODCID iD: http://orcid.org: 0000-0002-3098-0105

БЕСКОРОВАЙНАЯ, Л. В. - доктор педагогических наук, доцент, профессор кафедры туризма и гостинично-ресторанного дела

Запорожский национальный университет (Запорожье, Украина)

E-mail: 1vbeskorovaynaya@gmail.com

ORCID iD: https://orcid.org/0000-0001-9502-9604

\title{
НАПРАВЛЕНИЯ ЦИФРОВОЙ ТРАНСФОРМАЦИИ КРЕАТИВНЫХ ТЕХНОЛОГИЙ В СФЕРЕ ТУРИЗМА ПОСЛЕ УДАРА ПАНДЕМИИ СОVID-19
}

\begin{abstract}
Аннотация
Актуальность темы исследования состоит в том, что цифровая трансформация креативных технологий в сфере туризма рассматривается как важный элемент устойчивого развития экономики и общества в контексте до 2030 года. Креативные технологии, революция данных и цифровизация правительств являются ключевыми элементами и жизненно важными факторами содействия сотрудничеству между правительствами, частным сектором и гражданским обществом, способствующими повышению эффективности туристического сектора и предоставления услуг. Целью статьи является концептуализация цифровой трансформации креативных технологий в сфере туризма после удара пандемии COVID-19. Некоторые аспекты данной темы изучаются специалистами по цифровой трансформации креативных технологий в сфере туризма, потерпевшей удар после пандемии COVID-19, в частности влияние креативных инновационных технологий на устойчивое развитие туристической отрасли в Европе анализировались в статьях и аналитических докладах, на форумах и конференциях по туризму. Авторами использованы собственные работы по данной теме - Л.Бескоровайной, Н.Венгерской, В.Воронковой, А.Череп, А. Череп. Исследование основывается на использовании модифицированной информационно-логической модели, с помощью которой устанавливаются взаимосвязи между выявленными узкими местами в сфере
\end{abstract}

(C) Venherska, Natalia, Voronkova, Valentyna, Cherep, Alla, Cherep, Oleksandr, Bezkorovaina, Larysa 2021 
туризма, причинами их возникновения и возможными способами устранения этих причин, для чего разработаны практические рекомендации по усовершенствованию туристической отрасли, включая креативные цифровые зеленые технологии. Результат исследования. Проанализирована цифровая трансформация креативных технологий в сфере туризма как важный элемент устойчивого развития экономики и общества. Выявлены ключевые сферы цифровой трансформации креативных технологий в сфере туризма: вопрос изменения климата и восстановления мировой экономики. Раскрыты направления перехода к зеленым креативным технологиям как комплекс мероприятий по постпандемическому восстановлению. Выяснено развитие европейской парадигмы городского туризма в контексте диферсификации и развития внутреннего туризма. Адаптация к цифровой трансформации как существующей тенденции, ускоренной пандемией COVID-19, является одним из основных приоритетов развития цифровых технологий.

Ключевые слова: цифровая трансформация, креативные технологии, туризм, устойчивое развитие экономики, зеленые креативные технологии, постпандемическое восстановление туризма, городской туризм

(C) The Author(s) 2021

Received date 10.10.2021

This is an open access article under

Accepted date 01.11.2021

the Creative Commons CC BY license

Published date 14.11.2021

How to cite: Natalia Venherska, Valentyna Voronkova, Alla Cherep, Oleksandr Cherep \& Larysa

Bezkorovaina. Directions of creative technological digital transformation in touristic field after the impact of the COVID-19 pandemic. HUMANITIES STUDIES : Collection of Scientific Papers / ed. V. Voronkova. Zaporozhzhia : Publishing house «Helvetica», 2021. 9(86). P. 168-179.

doi: https://doi.org/10.26661/hst-2021-9-86-18

Directions of digital transformation of creative technologies in touristic field after the cob of the COVID-19 pandemic 